\title{
Tibetan Buddhist masters between two lives: \\ a closer look at the genre of bar do'i rnam thar using the example of the Seventh Karma pa, Chos grags rgya mtsho (1454-1506)
}

\author{
Dominik DELL
}

\begin{abstract}
This paper sets out to provide an overview of the little-researched genre of bar do'i rnam thar - an account of the experience of the intermediate state between two incarnations by Tibetan Buddhist masters. Representatives of this genre are identified, and the state of research and translation is summarised. This paper contributes to this field of research by providing an annotated translation, analysis, and critical edition of the so-far untranslated bar do'i rnam thar of the Seventh Karma pa from the mKhas pa'i dga'ston.
\end{abstract}

Keywords: Chos grags rgya mtsho, Karmapa VII, bar do'i rnam thar, mkhas pa'i dga' ston, Liberation Story of the In-Between State

Dominik Dell external PhD student at the Department of Philosophy of the Jagiellonian University, and student of Tibetan Studies at the International Institute for Tibetan and Asian Studies, Vélez-Málaga, Spain. His research interests include life stories of Tibetan Buddhist masters of the bKa' brgyud tradition as well as their works on philosophy. He is currently preparing his $\mathrm{PhD}$ thesis on the birth stories of several Karma pas.

E-MAIL: dominik.dell.research@gmail.com 


\section{Introduction}

While reading life stories (rnam thar) of Tibetan Buddhist masters, one comes across different levels of content, which classically can be divided into outer, inner, and secret life stories ${ }^{1}$. Secret life stories (gsang ba'i rnam thar) contain mystic events experienced by the protagonist, such as miraculous dreams, visions, and supernatural phenomena - all of them representing realisation of the nature of mind. While translating the life story of the Seventh Karma pa, I came across an account of his experiences during the intermediate state between death and rebirth ${ }^{2}$ at the transition from his sixth to his seventh incarnation, called bar do'i rnam thar ${ }^{3}$. Technically, the experiences in bar do'i rnam thars can be classified as a sub-category of the secret life story.

This section of the paper sets out to provide a primary overview of existing representatives of the genre of bar do'i rnam thar, as well as research on the topic. The representatives identified are mostly - with only few exceptions - among the Karma pas', the hierarchs of the Karma bKa' brgyud tradition and the first incarnation lineage in Tibet. The Tibetan texts have mostly been identified through an online search on the Buddhist Digital Resource Center (BDRC) ${ }^{4}$ website for the term bar do'i rnam thar and through mentions in research papers I came across. Hardly any texts bear this keyword in their title, and only a few texts have had their full text made searchable through OCR ${ }^{5}$. Usually, bar do'i rnam thars are not separate texts, but inserted into rnam thars, and sometimes without calling them by that name. All this gives reason to conjecture that there are probably a lot more representatives than those identified for this paper. Nevertheless, it seems the endeavour to consolidate known representatives has not been undertaken before. Therefore, this paper aims to contribute to that endeavour. For each Tibetan text identified, I try to provide both exact references to the Tibetan source, as well as, if applicable, a summary of the research done on it.

1 This classification is ascribed to sDe srid Sangs rgyas rgya mtsho (1653-1705) (Vostrikov 1994, 186-87). I would like to thank Artur Przybysławski, who encouraged me to write this paper and who kindly provided some feedback on an earlier version.

2 On the meaning of bar do, see Cuevas 2003, 39-68.

3 Sometimes also called rnam thar bar do ma, especially with respect to the Third Karmapa. See for example Manson 2009, 44, and Berounský 2010, 7.

4 Buddhist Digital Resource Center (BDRC) (access: 01.12.2019). In the following text, footnotes, and bibliography, I will very often use the abbreviation BDRC followed by an alphanumerical code by which the person, location or work can be found in the BDRC database.

5 OCR: Optical Character Recognition. 


\subsection{Third Karma pa, Rang byung rdo rje $(1284-1339)^{6}$}

Most of the research papers touching on bar do'i rnam thar circle around the Third Karma pa, Rang byung rdo rje 7 . In his introduction into the life of Karma Pakshi (1204/6-1283) ${ }^{8}$, Manson mentions the existence of a bar do'i rnam thar with respect to the transference of Karma Pakshi's consciousness to his third incarnation (Manson 2009, 44-43). Manson traces back the existence of a missing original bar do'i rnam thar text from an account and references in the Red Annals ${ }^{9}$ and from the reappearance of the account in the later Blue Annals (Roerich 1988, 487-88) ${ }^{10}$. It is also mentioned in Rang byung rdo rje's rnam thar in verse, but not told explicitly ${ }^{11}$. Accordingly, in the Collected Works of the Third Karma pa, this text is also indicated as missing ${ }^{12}$. Berounský dedicated a paper to this missing text (Berounský 2010). Gamble translated the bar do'i rnam thar of the Third Karma pa, which she found inserted into one of his life stories ${ }^{13}$. She presents some evidence that the content corresponds to the missing text (Gamble 2013, 301-2). This text is the longest I was able to identify so far of its kind, and most likely the earliest one, since the Karma pas were the first ones to establish the system of successive incarnations in Tibet. According to Gamble, the Second Karma pa, Karma Pakshi, called himself an "emanation" (rnam par 'phrul) of the First Karma pa, while claiming to have various other emanations at the same time. Only the Third Karma pa shifted focus from simultaneous emanations of a celestial being (as described by his predecessors) to concatenate lives and the idea of reincarnation (Gamble 2018, 78-80). His bar do'i rnam thar plays a crucial role in establishing this narrative by filling the gap between these successive incarnations. In Berounskýs words: "the sole existence of a text

6 I would like to thank Manfred Seegers, who helped me to get a clearer picture of the research on the bar do'i rnam thar of the Third Karma pa (e-mail communication in Nov 2019).

7 BDRC, P66. For more information on the Third Karma pa's life, see Seegers 2009, Gamble 2013, and 2018.

8 Second Karmapa (BDRC, P1487).

9 Tshal pa kun dga' rdo rje (1309-1364) 1981, 96. For a translation of the relevant paragraph, see Berounský 2011, 24-26.

10 For the Tibetan original, see 'Gos lo gzhon nu dpal (1392-1481) 1984.

11 Rang byung rdo rje, Karma pa III (1284-1339) 2006b.

12 The missing text is called Bar do'i rnam thar bstan pa, see Rang byung rdo rje, Karma pa III (1284-1339) 2006, dkar chag.

13 For the original, see Rang byung rdo rje, Karma pa III (1284-1339) 2006a, 358-66. For the translation, see Gamble (2013, 322-26). 
containing the detailed description of the events of the 'intermediate state' during reincarnation shows that in this case an effort was made to provide a variety of proofs confirming the genuineness of the 'repeated existence' of Karmapa" (Berounský 2010, 8).

\subsection{Fourth Karma pa, Rol pa'i rdo rje (1340-1383)}

The Fourth Karma pa, Rol pa'i rdo rje ${ }^{14}$, tells the account of his bar do state to dispel doubts towards his person. This account is told in his life story in the mKhas pa'i dga' ston ${ }^{15}$ and also in the later Kam tshang ${ }^{16}$. In the latter, the bar do'i rnam thar seems to follow the same story line and content, but the text is generally more extended. To my knowledge, neither of these texts has been translated nor researched to date. The function of this account might be similar to that of his direct predecessor's - consolidation of the still freshly established narrative of successive incarnations.

\subsection{Seventh Karma pa, Chos grags rgya mtsho (1454-1506)}

The bar do'i rnam thar of the Seventh Karma pa from the mKhas pa'i dga' ston $^{17}$ is to be translated and discussed in this paper. In the Kam tshang it is also briefly mentioned:

[The names of his parents are] also [retrieved] from his account of the intermediate state. In the North Amoghasiddhi said:

"You will be born into the world from the father, Grags pa dPal grub, and the mother, lHa mo skyid." [This] has been told by the tulku [Karma pa] himself afterwards. ${ }^{18}$

This short paragraph is the end of the longer bar do'i rnam thar in the mKhas pa'i dga' ston, and therefore, obviously copied from there.

${ }^{14}$ BDRC, P1456.

${ }^{15} \mathrm{dPa}$ ' bo gtsug lag 'phreng ba (1504-1564/1566) 1986, vol. 2, 950-51.

${ }^{16}$ Chos kyi 'byung gnas (1699/1700-1774) and 'Be lo Tshe dbang kun khyab (b. $18^{\text {th }}$ cent.) 1998 , $381-85$.

17 dPa' bo gtsug lag 'phreng ba (1504-1564/1566) 1986, vol. 2, 1032.

${ }_{18}$ Chos kyi 'byung gnas (1699/1700-1774) and 'Be lo Tshe dbang kun khyab (b. $18^{\text {th }}$ cent.) 1998 , 647. 


\subsection{Eighth Karma pa, Mi bskyod rdo rje (1507-1554)}

The bar do'i rnam thar of the Eighth Karma $\mathrm{pa}^{19}$ is not discussed much in research papers, but translations exist from different sources. Verhufen provides a German translation of it from the Kam tshang which covers approximately one page (Verhufen 1992, 75-76) ${ }^{20}$.

Rheingans translated a rather short version from one of his rnam thars in his Collected Works:

From when I died in the tiger year (stag lo, 1506) [as the Seventh Karmapa] until my rebirth in the hare year (yos lo, 1507), I stayed in [the pure realm of] Tusita with Maitreya and in [the pure realm] Sukhāvāti and was happy. Then, because I was tired of people, I thought it would be pointless to come here for the time being. When [thinking so] the protector Maitreya and the wisdom-ḍakinīs said, "you have to take rebirth in the world (jambudvippa)." Having taken rebirth I have until this year stayed in Lhorong (Rheingans $2010,280)^{21}$

Rheingans mentions another seemingly untranslated text, a rang rnam, that supposedly contains an account of the Karma pa's sojourn in the pure land of Maitreya (Rheingans 2017, 63) ${ }^{22}$.

\subsection{Other occurrences}

In the collected works of Karma chags med $(1613-1678)^{23}$ there is a text, untranslated to date, which has the term bar do'i rnam thar in its title (sPrul sku mi 'gyur rdo rjes gsungs pa'i bar do'i rnam thar slar tshigs bcad du phab pa 'khor ba dong sprugs) ${ }^{24}$. It can be translated as "A bar do'i rnam thar which

19 BDRC, $\mathrm{P}_{3} 85$. For a comprehensive overview of the life and work of the Eighth Karmapa, see Rheingans 2017.

${ }^{20}$ For the Tibetan original, see Chos kyi 'byung gnas (1699/1700-1774) and 'Be lo Tshe dbang kun khyab (b. $18^{\text {th }}$ cent.) 1998 , vol. $2,1-2$.

${ }^{21}$ For the Tibetan original, see A khu A khra dGe slong Byang chub bzang po (b. $16^{\text {th }}$ cent.) 2004, 82 (fol. 25b).

${ }^{22}$ For the Tibetan original, see Mi bskyod rdo rje, Karma pa VIII (1507-1554) 2004.

23 Karma chag med is an "important karma kaM tshang teacher and the founder of the gnas mdo branch of the kaM tshang bka' brgyud tradition" (BDRC, P649). Miroslav Hrdina from the University of Bonn, Germany, is currently preparing his $\mathrm{PhD}$ on Karma chag med (Hrdina, forthcoming).

${ }^{24}$ Karma chags med (1613-1678) 2010. 
has been told by the tulku Mi 'gyur rdo rje having come down [to us] in verse form - that which shakes out samsara completely". The title suggests that it contains the bar do'i rnam thar of Mi 'gyur rdo rje $\left(1645^{-1667}\right)^{25}$, who was a student of Karma chags med, the likely author of this text. The text - comprising 77 pages - not only contains this bar do'i rnam thar, but is used by Karma chags med as an occasion to elaborate on the meaning of this genre in general. He also gives many examples from other masters travelling between the different realms of existence and to the pure realms ${ }^{26}$. This text seems to be an interesting source for future exploration for at least two reasons. Firstly, it promises to provide not merely one more example of this genre, but hints about various other bar do'i rnam thars that might exist. Secondly, it could serve as a study of the genre from an emic perspective, rather than our Western etic perspective, since it seems to contain classifications and reflections on the genre by a master from within the tradition.

Berounský mentions an account of the intermediate state of the Sixth Dalai Lama, Tshangs dbyangs rgya mtsho $(1683-1706)^{27}$, about his transition from his fifth to his sixth incarnation. He states that, "in this much later text [compared to that of the Third Karma pa] the need for proofs of the veridicality of the new Dalai Lama becomes apparent" (Berounský 2010, 8) ${ }^{28}$. This Dalai Lama renounced his novice vows, was a composer of love poems, engaged in intimate relationships with women, and showed interest in various other amusements such as alcohol and singing ${ }^{29}$. He was obviously not as virtuous as the name of his school dge lugs ("School of the Virtuous Ones") suggests and not as virtuous as his predecessors. Therefore, one can easily imagine a situation where he had to prove his authenticity. A bar do'i rnam thar comes in handy as a means towards this end.

In the Collected Works of the $31^{\text {st }}$ Sa skya khri 'dzin, Ngag dbang Kun dga' blo gros $(1729-1783)^{30}$, there is an occurrence of the term bar do'i rnam thar.

25 BDRC, P659. Mi 'gyur rdo rjes outer life story, also written by Karma chags med, has been translated, but I could not find any hint of an account of his bar do experience there, which is not surprising, as it is explicitly titled as an "outer liberation story" (Karma Chagme 2008).

${ }^{26}$ Miroslav Hrdina has worked on this text and kindly shared some notes with me by e-mail on 5 Dec 2019. He plans to summarise and discuss this text in more detail in his $\mathrm{PhD}$ (Hrdina, forthcoming).

27 BDRC, $\mathrm{P}_{352}$. For an introduction into his life, see also Aris 1989.

${ }^{28}$ For the Tibetan source, see Sangs rgyas rgya mtsho (1653-1705) 1989.

29 Wickham-Smith 2012 (access: 15.12.2019).

30 BDRC, P805, and Schmidt 2015 (access: 15.12.2019). 
This case is interesting, since the Sa skya throne holders are not a succession of subsequent incarnations, but rather inherit their title. Nevertheless, they can be reincarnations of known lamas. The protagonist of the bar do'i rnam thar mentioned there could not be identified ${ }^{31}$.

There is a popular genre in Tibetan literature somewhat related to bar do'i rnam thar called 'das log ("those who have returned from the dead") stories of (more or less) ordinary people at the edge of dying. They experience the bar do state and then return to their present body and live on. These stories are sometimes also referred to as bar do'i rnam thars. They very much resemble what is called an account of a near-death experience in the West ${ }^{32}$. This is an interesting topic in itself, but out of scope for this paper. Only the accounts of the bar do experiences of realized masters, usually told in their new incarnation, are considered here.

\section{Translation}

\subsection{Introduction to the translation}

This section provides an annotated translation of the beginning part of the Seventh Karma pa's life story in the mKhas pa'i dga'ston, mainly containing his bar do'i rnam thar. For easier reference I inserted the page numbers of the three texts used for the critical edition into the translation - those of the original block-print $(\mathrm{A})^{33}$, those of one of the book versions $(\mathrm{B})^{34}$, and those of Chandra's handwritten edition $(\mathrm{C})^{35}$. For an overview of all texts used, see the introduction to the edition in the appendix. I divided the translation into two sections by inserting titles, which I refer to in the analysis section.

31 Kun dga' blo gros (1729-1783) 2008. This is a searchable eText in BDRC, but due to restrictions there is no PDF and the search output does not give the title of this text, which makes it extremely difficult to locate it in the dkar chag of other existing editions, which in turn are not searchable. Therefore, text title and page numbers cannot be provided.

32 Dixon 2017, 16-24, provides an overview of the state of research.

$33 \mathrm{dPa}$ ' bo gtsug lag 'phreng ba (1504-1564/1566) 1980, vol. 2, 184-86.

$34 \mathrm{dPa}$ ' bo gtsug lag 'phreng ba (1504-1564/1566) 1986, vol. 2, 1032-33.

35 dPa' bo gtsug lag 'phreng ba (1504-1564/1566) 1959-1965, vol. 2, 537-38. 


\subsection{Annotated translation ${ }^{36}$}

\section{[Death of the Sixth Karma pa and prophecy about his future incarnation]}

[A, vol. 2, p. 184, l. 7; B, vol. 2, p. 1032, l. 14; C, vol. 2, p. 537, l. 9] Concerning the circumstances of how the seventh incarnation appeared: [A, p. 185] previously, the dharma master, mThong ba don $\operatorname{ldan}^{37}$, gave [his] testament together with thirteen instructions to Go'i shri Rin po che ${ }^{38}$ during the days of the waxing moon of the twelfth month of the [water]-monkey year (1452). [Therein he] made a prophecy that [his] incarnation will appear in [a place] called sPyi lha ${ }^{39}$ in the northern region of [Tibet]. [He also mentioned] the father and the mother together with the place [of his birth]. [He] condensed [his] form body (rūpakāya) [in great bliss $]^{40}$ on the eighth day of the first month of the water-bird [year] (1453).

\section{[Intermediate state between death and rebirth of the Karma pa from his own account (bar do'i rnam thar)]}

Concerning the account of [his] intermediate state [between death and rebirth $]^{41}$, [the Karma pa] later communicated [the following]:

[I], the dharma master, [who is] an emanation of the bKa' brgyud [masters] and the buddhas and bodhisattvas, the victorious ones, will tell [my] concise account [which covers the period], when $[\mathrm{I}]^{42}$ had not yet been [re]born after [my] passing.

${ }_{36}$ I would like to thank Āchārya Choying Tendar for explaining to me various terms and phrases in the Tibetan text, which at first sight had remained obscure to me.

37 Name of the Sixth Karma pa (1416-1453); see BDRC, P1oo6.

$3^{8}$ Also known as the First mTshur pu rGyal tshab, dPal 'byor Don grub (1427-1489); see BDRC, P1380.

39 Possibly the same place as is referred to in BDRC, G1203. Otherwise, no reference found. Later on, in the text this place is also referred to as sPyi mda' mkha' and sPyi nang.

$4^{0}$ According to Āchārya Choying Tendar (oral communication in April 2015) the term gzugs sku bsdus is short for gzugs sku bde ba chen por bsdus which is used some lines later in the text. It comes down to meaning that he died.

${ }^{41}$ Tib. bar do. This is mostly rendered as "intermediate state". Though there are enumerations of different kinds of bar do, this term usually refers to the intermediate state between death and the next rebirth. The interested reader may be referred to Cuevas (2003, 39-68).

$4^{2}$ The pronoun bdag cag is the first person with a plural particle cag meaning "we", while I still rendered it as "I". Since this is a verse, cag might only be added to fulfil the meter. Or we can understand it in a general way as "when we have not yet been [re]born after [our] passing" in the sense of "when one has not yet been...". 
On the eighth day of the first month of the [water]-bird year [my] form body condensed in great bliss $(\text { mahāsukha })^{43}$ [and I] dwelled undistractedly ${ }^{44}$ in the state of clear light (prabhāsvara) ${ }^{45}$ [B, p. 1033].

Since at the same time ${ }^{46}$ as [my] corpse was cremated, [I] went to [the pure realm] Akaniștha ${ }^{47}$, [I] saw the Great Vajradhāra ${ }^{48}$ and Sākyamuni ${ }^{49}$ dwelling there in the form ${ }^{50}$ of the sambhogakā $y a^{51}$.

Moreover, inconceivable sambhogakāyas [and] lots of deities in exceeding number ${ }^{2}$ appeared [and I] encountered all those.

Vajradhāra also said: "Your father is called Grub pa ${ }^{53}$ and [your] mother [is] Sangs rgyas Khong nas Grub pas skyid ${ }^{54}$. Benefit for sentient beings will come about."

43 Tib. bde ba chen po means "great bliss" or, as a technical Sanskrit term, mahāsukha. It certainly refers to the state of great bliss that realized masters are said to experience at the time of death. Duff (2009) mentions it as "one of the seven attributes of the sambhogakaya", kha sbyor yan lag bdun - "the seven aspects of union". According to him, the "sambhogakaya form of a buddha is explained to have the nature of union in general and to have the nature of kha sbyor yan lag bdun ldan 'seven aspects of union' all together. The seven aspects are: 1) longs spyod rdzogs pa 'complete resources'; 2) kha sbyor 'union'; 3) bde ba chen po 'great bliss'; 4) rang bzhin med pa 'no self-nature'; 5) snying rjes yongs su gang ba 'totally filled with compassion'; 6) rgyun mi chad pa 'uninterrupted'; 7) 'gog pa med pa 'without stoppage'."

44 Tib. mnyam par bzhag. "This term refers to the ability to place the mind on an object and keep it there, undistractedly, for as long as one wants" (Duff 2009).

45 See Duff (2009) for a discussion of the term 'od gsal ( $b a$ ). He claims that "clear light" is a misunderstood translation and it should rather be "illumination". To avoid such discussions, one may choose the Sanskrit term. Nevertheless, I use the term "clear light" here as a common translation.

$4^{6}$ Tib. mnyam $d u$, here understood in a temporal sense.

47 Tib. 'og min. This is considered to be the highest pure realm "which is a Sambhogakāya realm where $10^{\text {th }}$ bhūmi bodhisattvas receive teachings from the true Sambhogakāyas" (Duff 2009).

$4^{8}$ Tib. rdo rje 'chang chen.

49 Tib. thub pa.

50 Tib. cha lugs, literally "dress", here referring to the dress, ornaments, and so on that are typical for the sambhogakāya.

51 Tib. longs sku, the enjoyment body, Skt. sambhogakāya.

${ }^{22}$ Tib. lhag pa'i lha. This special deity (lhag pa'i lha) is the deity (yi dam gyi lha), which one uses in one's principal practice (Duff 2009). However, this meaning doesn't fit very well here. Therefore, I would rather understand lhag pa as "to exceed", i.e. "deities in exceeding number".

53 His full name and title is Grub thob Grags pa dPal grub (BDRC, P1378).

54 In BDRC her name is only given as $\mathrm{HHa}$ mo skyid (BDRC, P1379). It seems that Sangs rgyas Khong nas Grub pas skyid is an etymological interpretation of her name trying to explain why she is "happy" (skyid) including the name of the father in this interpretation (grup pa). Hence, it seems to be just some playing with the words rather than her real name. 
In accordance with his utterance, [I] trained in the samphogakāya realm and then in Tusita [heaven] ${ }^{55}$ Maitreya ${ }^{56}$ said: "Please, bring unfathomable benefit to beings!"

In Abhirati ${ }^{57}$ Akśobhya ${ }^{58}$ said: "From the householder to the fully renounced one, benefit others as a lay practitioner $(u p \bar{a} s a k a)^{59}$, novice (śr $\bar{a}-$ manera $)^{60}$, fully ordained monk (bhikșu $)^{61}$, and through the Vajrayāna."

In the South, Ratnasambhava said: "Previously, unfathomable benefit occurred through you. Now again, please think of the ones to be tamed in the world $^{62}$ (jambudvipa $)^{63}$ and bring benefit [to them]."

In Sukhāvatīi ${ }^{64}$, Amitābha ${ }^{65}$ asked: "Have you provided benefit to sentient beings before?" Since [I] answered ${ }^{66}$ : “[I] did provide [benefit]!", [he] now added: "Please, provide benefit to sentient beings through the Six Pāramitās ${ }^{67}$ once again."

[A, p. 186] When [I] came to the seat rows of the gathering of the diakinīs in Oḍ̣iyāna ${ }^{68}$ [they] asked [me]: "Who are you?" I said: "[I] am mThong

55 Tib. dga' ldan, "Tuṣita (Heaven)". "Tuṣita is the dwelling place at any time of the $10^{\text {th }}$ bhumi bodhisattva who is waiting to descend as the next buddha" (Duff 2009).

${ }^{6}$ Tib. byams pa, lit. "the one of loving kindness", future buddha.

57 Tib. mngon dga', lit. "manifest joy", the pure realm of Akśobhya (in the East, when considering the five buddhas).

$5^{8}$ Tib. mi khrungs pa, lit. "the unshaking", the name of the buddha at the head of the vajra family, also called mi bskyod ba (Duff 2009).

59 Tib. dge bsnyen, Skt. upāsaka, lay practitioner.

6o Tib. dge tshul, Skt. śrāmaṇera, novice.

61 Tib. dge slong, Skt. bhikșu, fully ordained monk.

${ }^{62}$ Tib. 'dzam gling gi gdul bya. According to Āchārya Choying Tendar (oral communication in May 2015) this term refers to all sentient beings, as they need the help of enlightened beings such as the Karma pa as their teachers.

63 Tib. 'dzam gling, Skt. jambudvipa, lit. "continent of the rose apple tree", used in Buddhist cosmology to denote one of the four continents. In a wider sense it is used as a synonym of 'jig rten - "(human) world".

${ }_{4}$ Tib. bde ba can, lit. "having bliss", pure realm of Amitābha.

65 Tib. 'od dpag med, lit. "measureless light", the name of the buddha at the head of the lotus family (Duff 2009).

${ }^{66}$ Tib. zhus pa, here the Karma pa speaks in first person, therefore, for Amitābha the honorific verb gsungs is used, whereas for the Karma pa the humilific verb zhus is applied.

${ }_{67}$ Tib. pha rol tu phyin pa drug. The Six Paramitās are the practice of a bodhisattva or of those who want to become one. They are sbyin pa ("generosity"), tshul khrims ("discipline"), bzod pa ("patience"), brtson 'grus ("perseverance"), bsam gtan ("concentration"), and shes rab ("prajña") (Duff 2009).

68 Tib. O rgyan or U rgyan, the place Guru Padmasambhava came from, corresponds to za hor, 
ba don ldan ${ }^{69}$, [who] previously has been the completely pure birth of Dus gsum mkhyen $\mathrm{pa}^{70}$, Karma Pakshi ${ }^{71}$, Rang byung rdo rje ${ }^{72}$, Rol pa'i rdo rje ${ }^{73}$ [C, p. 538], and De bzhin gshegs pa ${ }^{74}$." [They] replied: "Well then, if that is the case, [we] ask [you to be] the feast master ${ }^{75}$." And [I] performed [the role of] the vajra-master ${ }^{76}$. All diakinīs promised to accomplish the enlightened activity.

In the North, Amoghasiddhi ${ }^{77}$ said: "You will be born into the world from the father, Grags pa $\mathrm{dPal}_{\text {grub }}{ }^{78}$, and the mother, lHa mo skyid ${ }^{79}$." [This account of the bardo state] has been told by the tulku ${ }^{80}$ himself afterwards.

\section{Analysis}

Having presented an annotated translation in the previous section, I would like to add to it by analysing the text. To this end, the paragraph preceding the bar do'i rnam thar is briefly analysed to frame the work, before proceeding to the actual bar do'i rnam thar. The content of both paragraphs is summarised and the major events are analysed by explaining them against the background of other research or tradition or by relating them to other sources. Finally, possible functions of certain paragraphs are discussed.

which is the name of a country in ancient times in the Northwest of India where Buddhist tantra flourished (Duff 2009).

69 Name of the Sixth Karma pa (1416-1453) (BDRC, P1006).

$7^{70}$ Name of the First Karma pa (1110-1193) (BDRC, P1400).

${ }^{71}$ Name of the Second Karma pa (1204/o6-1283 (BDRC, P1487).

${ }^{72}$ Name of the Third Karma pa (1284-1339) (BDRC, P66).

73 Name of the Fourth Karma pa (1340-1383) (BDRC, P1456).

${ }^{74}$ Name of the Fifth Karma pa (1384-1415) (BDRC, P1410).

75 Tib. tshogs kyi slob dpon.

${ }^{76}$ Tib. rdo rje'i slob dpon. This is a synonym to tshogs kyi slob dpon (Duff 2009).

77 Tib. don yod grub pa, lit. "accomplisher of what is meaningful", name of the buddha at the head of the Karma family (Duff 2009).

${ }^{8}$ See BDRC, P1378.

79 See BDRC, P1379.

80 Tib. sprul sku, Skt. nirmānakāya. This term denotes the emanation body of a buddha, which he uses to enter the world and to act as a bodhisattva. In a narrower sense it also denotes "the title given in the Tibetan tradition to beings who have been officially recognized as re-incarnations of a previous, great being” (Duff 2009). 


\subsection{Death of the Sixth Karma pa and prophecy about his fu- ture incarnation}

The text starts with a reference to the testament of the Sixth Karma pa, which contains a prophecy of who the parents of the Seventh Karma pa would be and where he would be born, followed by a reference to the death of the Sixth Karma pa. Why is that? The Karma pas form a lineage of successive incarnations. Here the rnam thar makes the connection between two successive incarnations. Thereby, the Seventh Karma pa's position in the lineage is certified. This corresponds to one class of the threefold classification of rnam thars coined by Roesler (2014, 119ff.). According to her, this kind of rnam thar defines the identity of the particular school and establishes the place of a certain master within the lineage ${ }^{81}$. Besides, the knowledge of place and parents of his future rebirth demonstrates the Karma pa's superior spiritual attainments.

\subsection{Intermediate state between death and rebirth of the Karma pa from his own account (bar do'i rnam thar)}

This paragraph contains the actual bar do'i rnam thar. It has the following structure:

- At the time of death, the Karma pa's form body condenses in great bliss (mahāsukha) and he dwells undistractedly in the state of clear light (prabhāsvara)

- Meeting with Vajradhāra and Śākyamuni (and further saṃbhogakāyas and deities) in the pure realm Akaniṣtha; Vajradhāra prophesies the names of his future parents

- Meeting with the future Buddha Maitreya in Tusita heaven; request to bring benefit to beings

- Meeting with Akṣobhya in his pure realm Abhirati; request to benefit beings on different levels

- Meeting with Ratnasambhava in the South; request to bring benefit to beings

- Meeting with Amitābha in his pure realm Sukhāvatī; request to bring benefit to beings through the Six Pāramitās

${ }^{81}$ For more information about the Karma bka' brgyud lineage, which the Karma pas head, see Stott 1980. 
- Meeting with the Dākinīs in Oḍdiyāna; enumeration of his previous incarnations as the Karma pa; they make him the vajra-master and promise to accomplish the enlightened activity

- Meeting with Amoghasiddhi in the North; he prophesies the names of his future parents

At the time of his death, the Sixth Karma pa condenses his form body (rūpakāya) in great bliss (mahāsukha) which, as mentioned earlier, is "one of the seven attributes of the sambhogakaya" (Duff 2009, kha sbyor yan lag bdun). Since he becomes a sambhogakaya himself, he is able to meet different buddhas and sambhogakayas in the pure realms. These buddhas ask him to provide benefit to beings. In my view, this paragraph has at least a two-fold function.

First, like the preceding paragraph, it is still not about the Seventh Karma pa's life, but recalls a series of events that happens in the intermediate state between death and rebirth. Thereby, again emphasising the continuation of the mind-stream of the different Karma pas across different lives, it shares the function of the first paragraph of embedding the new incarnation into the lineage.

Second, it illustrates the extraordinary realisation of the Karma pas. It is not normal to have memories of meetings with all kinds of buddhas from the period between one life and the next, not even for members of incarnation lineages. This emphasises the greatness of the Karma pas' realisation. Further, it is not simply about meeting buddhas, but each and every buddha he meets asks him to bring benefit to beings. This illustrates that he works together with the buddhas and that the buddhas deem him capable of fulfilling the requested activity, and thus he is given the highest authorisation. Additionally, if we look at the title "Karma pa", it means exactly this - "the one [who performs] the activity of [all] buddhas"82. As Gamble points out, it is said that the Karma pa will become the sixth buddha of this eon, Simha, and every buddha trains with his predecessor in Tusita - which in Karma pa's case would be Maitreya (Gamble 2018, 137) ${ }^{83}$. Hence, this paragraph shows the Karma pa not only as a great bodhisattva, but even as a Buddha to-be.

82 If one sees karma as a synonym for phrin las, "Buddha activity", or if one considers the long form of the title "Karma pa" given as "Karma phrin las pa" (Duff 2009). See also Rheingans 2010, 249, footnote 35 .

83 See also Jamgön Kongtrul Lodrö Tayé 2010, 349: "The future sixth buddha, Lion's Roar, in the guise of a bodhisattva, appears as the Karmapas." 
As outlined in the introduction, there are bar do'i rnam thars of several Karma pas. For instance, in that of the Third Karma pa, Maitreya is only briefly mentioned and then there is a lengthy discussion with the dākinīs, who try to convince Karma pa to take birth again to help beings, which at first he refuses (Gamble 2013, 322-26). This account depicts Karma pa as rather personal or human, as someone expressing doubts, not wanting to be reborn. In contrast, the Seventh Karma pa's account does not depict someone so human, but rather shows him as a buddha meeting all other buddhas, being one of them and knowing exactly what he needs to do. The appearance of the future Buddha Maitreya and the meeting with the diakinis seems to be a pattern linking the different accounts of the Karma pas. It is also present in the Eighth Karma pa's account. There he is also depicted in a human way, in the sense that he does not want to take rebirth at first, and Maitreya and

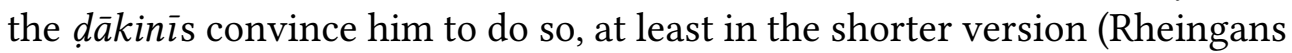
2010, 280). In the longer version, Karma pa is depicted as rather perfect (Verhufen 1992, 75-76). For the time being the Seventh Karma pa's account seems to be unique as he systematically meets all the different buddhas. There are meetings with the past Buddha, Sākyamuni, the future Buddha, Maitreya, the essence of all buddhas, Vajradhāra, and the five transcendental buddhas, one after the other, which are said to have manifested from Vajradhāra. This clearly underlines the full support of all buddhas and the depth of the realisation of Karma pa.

The meeting with the dākinis in these accounts might emphasise the special relationship between Karma pa and the dākiniss. The First Karma pa, Dus gsum mkhyen pa (1110-1193), is said to have attained enlightenment through dream yoga, after being visited by fifteen wisdom dia kinins. According to legend, "[at] the moment of his enlightenment an ornate black crown [...] appeared above the Karma pa's head, woven from the hair of hundred thousand dẹkinīs, symbolizing his knowing of the past, present and future" (Simmer-Brown 2001, 251). This crown is said to be an energy-field, while the black crown worn by the Karmapas at solemn occasions was given only to the Fifth Karma pa, bDe bzhin gshegs pa (1384-1415), by the emperor of China. According to Simmer-Brown, the "hair is an intimate, personal aspect of the dākinī's body, signifying the close experiential contact between disciple and teacher" and the act of surrendering one's hair is a sign of renunciation, similar to the cutting of a lock of hair at the Buddhist refuge ceremony (Simmer-Brown 2001, 251). In this way, in the case of the Seventh Karma pa, 
the $\underline{d a}$ akinis confirm this already existing relationship in the bar do'i rnam thar by making him the vajra-master and by promising to accomplish the enlightened activity.

In the introduction it was mentioned that one reason for a bar do'i rnam thar might be the need to prove the authenticity of a particular incarnation. This applies, for instance, to the Eighth Karma pa, who had a rival candidate (Rheingans 2010, 268-70). Concerning the Seventh Karma pa, there were also two candidates, one of whom was later identified as the Fourth Zhwa dmar pa, Chos grags ye shes (1453-1524). This is also mentioned a bit later in the rnam thar at hand ${ }^{84}$. For the Third and Fourth Karma pas, the need to prove their authenticity might rather have been the project of establishing the incarnation lineage.

A formal aspect that should be noted is that the bar do'i rnam thar is written in the Karma pa's direct speech and composed in metre. The direct speech could have been utilised to increase the credibility of events, since no one else could actually have witnessed them. And the metre might be used to adorn the Karma pa's speech with elegance to underline his superiority. These aspects are also similar for the other analysed representatives of this genre.

\section{Conclusion}

My contribution to research in the genre of bar do'i rnam thar is an annotated translation, analysis, and critical edition of the so far untranslated bar do' $i$ rnam thar of the Seventh Karma pa from the mKhas pa'i dga'ston. This is an example of a study that would have to be done with all bar do'i rnam thars of this lineage and possibly other lineages.

Based on the overview I provided in the introduction, I see many interesting possibilities for further research on bar do'i rnam thars. A translation of the bar do'i rnam thar of the Fourth Karma pa from the two sources mentioned could be a valuable addition. Further, it could be promising to examine the life stories of the other Karma pas for any other bar do'i rnam thars, since examples in this genre have already been identified for four of the Karma pas. This would also facilitate a systematic comparison of the different Karma pa bar do'i rnam thars with respect to content, form, length,

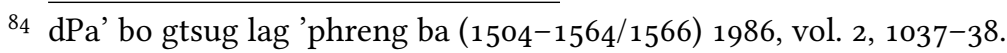


intention, circumstances, function, and so on. This paper has already pointed out some common patterns and some differences - common patterns being the meeting with Maitreya and the dākinīs, differences being how human or perfect the Karma pa is depicted. Another interesting subject would be to study Karma chags med's elaboration on the genre mentioned earlier. This promises to provide new insights on how this genre is perceived within the tradition. It might also be interesting to compare bar do'i rnam thars of other traditions - for instance that of the Sixth Dalai Lama ( $d G e$ lugs) or of Mi 'gyur rdo rje ( $r N y i n g ~ m a)$ - with those of the Karma pas ( $b \mathrm{Ka}$ ' brgyud). Karma chags med's text might also provide more hints on further extant bar do'i rnam thars.

\section{Appendix: Edition}

\subsection{Introduction to the edition}

All editions of the mKhas pa'i dga'ston, which I could identify are based on the 1 Ho brag printing blocks. According to Richardson (1959, x), referring to the colophon of these blocks, they were originally stored in gNas bzhis, a bKa' brgyud monastery, in 1 Ho brag, but were later moved to lHa lung monastery, also in 1 Ho brag, where he and Lokesh Chandra got some copies from ${ }^{85}$. I could not find any evidence or hint of other printing blocks of the mKhas pa'i dga' ston.

I could identify five textual witnesses of the mKhas pa'i dga' ston, of which the most interesting and original one is a reproduction of prints from the 1 Ho brag blocks from Rumtek Monastery in two volumes from $1980^{86}$. This reproduction is also available via BDRC, and I took this as a starting point for the edition I provide here. All other textual witnesses are derived from these printing blocks' text more recently.

Lokesh Chandra already published the mKhas pa'i dga'ston in four volumes from 1959 to $1965^{87}$. This edition is based on a print from the lHo brag blocks he had made, but it has been copied and handwritten in calligraphy ${ }^{88}$.

85 Richardson (1959, x) or Chandra (dPa' bo gtsug lag 'phreng ba (1504-1564/1566) 1959-1965), respectively, do not mention when that was, but it must have been before Chandra issued his edition, that is, before 1959. I have no information as to whether these blocks still exist today.

${ }^{86} \mathrm{dPa}$ ' bo gtsug lag 'phreng ba (1504-1564/1566) 1980.

$87 \mathrm{dPa}$ ' bo gtsug lag 'phreng ba (1504-1564/1566) 1959-1965.

$88 \mathrm{dPa}$ ' bo gtsug lag 'phreng ba (1504-1564/1566) 1959-1965, vii, and Richardson (1959, x). 
rDor je rgyal po made a modern edition in book format, which has been published by Mi rigs dpe skrun khang, first in 1986 in two volumes, then in 2006 in one volume, and again in 2015 in one volume ${ }^{89}$. The first two are available via BDRC, while the third is subject to restricted access in BDRC $^{90}$. Since all three editions are from the same publishing house and editor, I assume that the 2006 and 2015 editions do not add information to the 1986 edition. Therefore, apart from the reproduction of the original blockprint $\left(\mathrm{A}^{91}\right)$ and Chandra's handwritten version $\left(\mathrm{C}^{92}\right)$, I only considered the 1986 edition $\left(\mathrm{B}^{93}\right)$ for the critical edition provided here ${ }^{94}$. My impression is that Chandra's version is rather close to the blockprint reproduction, only showing a few differences in spelling. However, it was also useful to consider rDo rje rgyal po's edition, since the latter corrects many spelling mistakes or nonstandard spellings from the original. For instance, texts $\mathrm{A}$ and $\mathrm{C}$ frequently read gsung where one would expect gsungs. In some cases text B corrects spelling errors of text $A$, in other cases it has new misspellings. If there are differences, I indicate in the apparatus which variants are in which text, and which reading I decided on. For instance "gsungs B ] gsung A, C" means that I decided to read gsungs according to text $\mathrm{B}$, while texts $\mathrm{A}$ and $\mathrm{C}$ actually read gsung. Generally, there are no significant differences in the section I studied. The guiding theme of the critical edition is classical Tibetan grammar and orthography.

In the critical edition below, if a new page starts the page numbers of all three texts are indicated in brackets.

\subsection{Critical edition}

(A, vol. 2, p. 184, 1. 7; B, vol. 2, p. 1032, 1. 14; C, vol. 2, p. 537, 1. 9) de la sprul pa'i sku bdun pa ji ltar byon pa'i tshul ni / sngon (A, p. 185) chos kyi rje mthong ba don ldan gyis spre lo zla ba bcu gnyis pa'i yar tshes la go'i shri rin po che la zhal chems bka' rgya bcu gsum dang bcas pa gnang byang phyogs spyi lha zhes bya bar sprul sku 'byon par yab yum yul bcas lung bstan te ${ }^{95}$ chu bya zla ba dang po'i tshes brgyad la gzugs sku bsdus /

\footnotetext{
89 dPa' bo gtsug lag 'phreng ba (1504-1564/1566) 1986, 2006, and 2015.

90 Buddhist Digital Resource Center, (access: 22.12.2019).

${ }^{1} \mathrm{dPa}$ ' bo gtsug lag 'phreng ba (1504-1564/1566) 1980, vol. 2, 184-86.

$92 \mathrm{dPa}$ ' bo gtsug lag 'phreng ba (1504-1564/1566) 1959-1965, vol. 2, 537-38.

93 dPa' bo gtsug lag 'phreng ba (1504-1564/1566) 1986, vol. 2, 1032-33.

94 These three editions are also mentioned in Martin 1997, 88-89.

95 te $\mathrm{B}, \mathrm{C}]$ ste $\mathrm{A}$
} 
bar do'i rnam thar ni phyis nyid kyi gsung las /

bka' brgyud rnams dang sangs rgyas byang chub sems /

/ rgyal ba rnams kyi rnam 'phrul chos kyi rje /

/'das nas bdag cag ma skyes par ${ }^{96}$ /

/ rnam thar bsdus pa brjod par bya /

/ bya lo zla ba dang po'i tshes brgyad la /

/ gzugs sku bde ba chen por bsdus pa yin /

/'od gsal ngang la mnyam par bzhag/

/gdung bzhus mnyam du'og min du /

/ phyin pas rdo rje 'chang chen dang /

/ thub pa (B, p. 1033) longs sku'i cha lugs 'dug pa mthong /

/ gzhan yang longs sku bsam mi khyab /

/ lhag pa'i lha yang mang po snang /

/ de rnams thams cad dang ni mjal /

/ rdo rje 'chang gi gsung las kyang /

/ khyod ${ }^{97}$ kyi pha ni grub pa ces bya ba /

/ ma ni sangs rgyas khong nas grub pas skyid /

/ sems can rnams la phan pa 'byung ba yin /

/ zhes gsungs pa ltar longs sku'i zhing sbyangs te dga' ldan du byams pas khyod kyis 'gro don dpag tu $u^{98}$ med pa gyis shig99 gsungs $^{100} /$ mngon dgar mi 'khrugs ${ }^{101}$ pas khyod khyim nas khyim med par rab tu byung la dge bsnyen dang dge tshul dang dge slong dang rdo rje theg pas gzhan phan gyis gsungs ${ }^{102} /$

${ }_{96}$ par B ] bar A, C

97 khyod $\mathrm{A}, \mathrm{C}$ ] khyed $\mathrm{B}$

${ }_{98}^{8}$ tu $\left.\mathrm{A}, \mathrm{B}\right] d u \mathrm{C}$

$99 \operatorname{shig} \mathrm{B}] \operatorname{cig} \mathrm{A}, \mathrm{C}$

${ }^{100}$ gsungs $\mathrm{B}$ ] gsung A, C

101 'khrugs B ] 'khrug A, C

102 gsungs $\mathrm{B}$ ] gsung $\mathrm{A}, \mathrm{C}$ 
lho phyogs su rin chen 'byung ldan gyis khyod kyis sngon 'gro don dpag med byung/

da yang 'dzam gling gi gdul bya la soms la 'gro don gyis shig ${ }^{103}$ gsungs $^{104} /$

bde ba can du 'od dpag med kyis khyod kyis sngon sems can la phan thogs sam gsungs ${ }^{105} /$

thogs zhus pas da yang pha rol tu ${ }^{106}$ phyin pa drug gis sems can la phan thogs shig $^{107}$ gsungs $^{108} /$

O rgyan du mkha' (A, p. 186) 'gro'i tshogs gral du byon pas khyod su yin gsungs ${ }^{109}$ / nga ni sngon chad dus gsum mkhyen pa dang/

/karma pakshi ${ }^{110}$ rang byung rdo rje dang/

/rol pa'i (C, p. 538) rdo rje de bzhin gshegs pa yi/

/skye ba rnam dag mthong ba don ldan yin/

/zhes gsungs pas 'o na tshogs kyi slob dpon zhu gsungs ${ }^{111} t^{112}$ rdo rje'i slob dpon mdzad/ mkha' 'gro thams cad kyis 'phrin las sgrub par dam bcas/

byang phyogs su don yod grub pas khyod dzambu'i gling du pha grags pa dpal grub dang ma lha mo skyid ${ }^{113}$ las skye bar 'gyur ro gsungs ${ }^{114}$ zhes phyis sprul sku nyid kyis bka' bstsal/

103 shig B ] cig A, C

104 gsungs B ] gsung A, C

${ }_{105}$ gsungs B ] gsung A, C

$106 t u \mathrm{~A}, \mathrm{C}] d u \mathrm{~B}$

107 shig B ] $\operatorname{cig} \mathrm{A}, \mathrm{C}$

${ }_{108}$ gsungs B ] gsung A, C

109 gsungs B ] gsung A, C

110 karma pakshi A, C ] karma pagshi B

111 gsungs $\mathrm{B}$ ] gsung A, C

112 te B ] ste A, C

113 ma lha mo skyid A, B ] lha mo skyid C

114 gsungs B ] gsung A, C 


\section{Bibliography}

\section{Tibetan literature}

A khu A khra dGe slong Byang chub bzang po (b. $16^{\text {th }}$ cent.). 2004. "rGyal ba kun gyi dbang po dpal ldan karma pa mi bskyod rdo rje'i zhabs kyi dgung lo bdun phan gyi rnam par thar pa nor bu'i phreng ba." In $\mathrm{dPal}$ rgyal ba karma pa sku 'phreng brgyad pa mi bskyod rdo rje'i gsung 'bum, mainly authored by Mi bskyod rdo rje. Vol. 1, 33-106, 37 fols. lHa sa: s.n. BDRC, W8039.

Chos kyi 'byung gnas (1699/1700-1774), 'Be lo Tshe dbang kun khyab (b. $18^{\text {th }}$ cent.). 1998. sGrub brgyud karma kam tshang brgyud pa rnam thar rin po che'i rnam par thar pa rab 'byams nor bu zla ba chu shel gyi phreng ba. Kun ming: Yun nan mi rigs dpe skrun khang. BDRC, W24686.

dPa' bo gtsug lag 'phreng ba (1504-1564/1566). 1959-1965. Mkhas pahi dgah ston by Dpah-bo-gtsug-lag 'phreng-ba (4 volumes). Edited by Lokesh Chandra. Śatapitaka Series no. 9[4]. New Dehli: International Academy of Indian Culture. BDRC, $\mathrm{W}_{1} \mathrm{KG}_{2} 4245$.

- 1980. Chos 'byung mkhas pa'i dga'ston (2 volumes). Reproduced from prints from lHo brag blocks from Rumtek Monastery. Dehli: Dehli Karmapa Chhodhey Gyalwae Sungrab Partun Khang. BDRC, W28792.

- 1986. Chos 'byung mkhas pa'i dga'ston (2 volumes). Edited by rDo rje rgyal po. Bejing: Mi rigs dpe skrun khang. BDRC, $\mathrm{W}_{7499 .}$

- 2006. Chos 'byung mkhas pa'i dga'ston. Edited by rDo rje rgyal po. Bejing: Mi rigs dpe skrun khang. BDRC, W1PD96069.

- 2015. Chos 'byung mkhas pa'i dga'ston. Edited by rDo rje rgyal po. Bejing: Mi rigs dpe skrun khang. BDRC, W8LS19006.

'Gos lo gzhon nu dpal (1392-1481). 1984. Deb ther sngon po. Khreng tu'u: Si khron mi rigs dpe skrun khang. BDRC, $\mathrm{W}_{1} \mathrm{KG}_{5762 .}$

Karma chags med (1613-1678). 2010. mKhas grub karma chags med kyi gsung 'bum ngo mtshar nor bu'i bang mdzod. Nang chen rdzong: gNas mdo gsang sngags chos 'phel gling gi dpe rnying nyams gso khang. BDRC, W1KG8321.

Karma gling pa (b. 14th cent.). 2003. Bar do thos grol chen mo. Edited by mKhan po rdo rje. Zhang kang: Zhang kang then ma dpe skrun khang. BDRC, W29145. 
Kun dga' blo gros (1729-1783). 2008. Ngag dbang kun dga' blo gros kyi gsung 'bum. Bouddha, Kathmandu: Sa skya rgyal yongs gsung rab slob gnyer khang. BDRC, W3JT13306.

Mi bskyod rdo rje, Karma pa VIII (1507-1554). 2004. "rGyal ba karma pa mi bskyod rdo rje'i rnam thar bdag tshul bcu gnyis". In dPal rgyal ba karma pa sku 'phreng brgyad pa mi bskyod rdo rje'i gsung 'bum, vol. 1, 488-507. 1Ha sa: s.n. BDRC, W8039.

Rang byung rdo rje, Karma pa III (1284-1339). 2006. Karma pa rang byung rdo rje $i$ gsung 'bum. Zi ling: mTshur phu mkhan po lo yag bkra shis. BDRC, W30541.

. 2006a. "dPal chen rang byung rdo rje'i rnam thar." In Karma pa rang byung rdo rje'i gsung 'bum, vol. nga, 353-373. Zi ling: mTshur phu mkhan po lo yag bkra shis. BDRC, W30541.

- 2006b. Thams cad mkhyen pa rin po che rang byung rdo rje'i rnam par thar pa tshigs su bcad pa. In Karma pa rang byung rdo rje' $i$ gsung 'bum, vol. nga, 374-415. Zi ling: mTshur phu mkhan po lo yag bkra shis. BDRC, W30541.

Sangs rgyas rgya mtsho (1653-1705). 1989. "sKu lnga pa drug par 'pho ba'i dgongs pa gtad phyogs dang/ 'da' kha'i zhal chems yang srid myur 'byon gyi mtshan rtags skor". In Tshangs dbyangs rgya mtsho'i rnam thar, 50-71. lHa sa: Bod ljongs mi dmangs dpe skrun khang. BDRC, W8222.

Tshal pa kun dga' rdo rje (1309-1364). 1981. Deb ther dmar po rnams kyi dang po hu lan deb ther. Beijing: Mi rigs dpe skrun khang, 1981. BDRC, $\mathrm{W}_{1} \mathrm{KG}_{5760 .}$

\section{Western literature}

Aris, Michael. 1989. Hidden Treasures and Secret Lives: A Study of Pemalingpa (1450-1521) and the Sixth Dalai Lama (1683-1706). London: Kegan Paul International.

Berounský, Daniel. 2010. "Entering Dead Bodies and the Miraculous Power of the Tibetan Kings: The Landmark of Karma Pakshi's Reincarnation in Tibet. Part I.", Mongolo-Tibetica Pragensia '1o, Linguistics, Ethnolinguistics, Religion and Culture, 3(2): 7-33.

- 2011. "Entering Dead Bodies and the Miraculous Power of the Tibetan Kings: The Landmark of Karma Pakshi's Reincarnation in Tibet. Part II." Mongolo-Tibetica Pragensia '11, Linguistics, Ethnolinguistics, Religion and Culture, 4(2): 7-29. 
Buddhist Digital Resource Center (BDRC) (access: 01.12.2019 to 22.12.2019). Cuevas, Bryan. 2003. The Hidden History of the Tibetan Book of the Dead. Oxford: Oxford University Press.

Dixon, Joe. 2017. "Death and Afterlife in Tibetan Buddhist Biography. The rnam thar of Karma dbang 'dzin." Master's thesis. University of Oxford.

Duff, Tony. 2009. The Illuminator Tibetan-English Encyclopaedic Dictionary, 5.17 ed. Kathmandu, Nepal: Padma Karpo Translation Committee.

Gamble, Ruth Ellen. 2013. "The View From Nowhere: The Travels of the Third Karmapa, Rang byung rdo rje in Stories and Songs.” PhD diss. The Australian National University, Canberra.

- 2018. Reincarnation in Tibetan Buddhism. The Third Karmapa and the Invention of a Tradition. New York: Oxford University Press.

Hrdina, Miroslav. Forthcoming. "The Life of Karma Chags-med (1613-1678) according to his Autobiography (rang-rnam).” PhD diss. University of Bonn.

Jamgön Kongtrul Lodrö Tayé. 2010. The Treasury of Knowledge. Books Two, Three and Four: Buddhism's fourney to Tibet, Ngawang Zangpo (trans. and introduction). Snow Lion Publications. Ithaca. New York.

Karma Chagme. 2008. The All Pervading Melodius Sound of Thunder: The Outer Liberation Story of Terton Migyur Dorje. Translated by Lopon Sonam Tsewang and Judith Amtzis. Pharping, Nepal: Palri Parkhang.

Manson, Charles. 2009. "Introduction to the Life of Karma Pakshi." Bulletin of Tibetology, 45: 25-51.

Martin, Dan, and Yael Bentor. 1997. Tibetan Histories: A Bibliography of Tibetan-language Historical Works. London: Serindia Publications.

Rheingans, Jim. 2010. "Narratives of Reincarnation, Politics of Power, and the Emergence of a Scholar: The Very Early Years of Mikyo Dorje." In Lives Lived, Lives Imagined-Biography in the Buddhist Tradition, edited by Linda Covill, Ulrike Roesler, and Sarah Shaw, 241-98. Boston: Wisdom Publications.

- 2017. The Eighth Karmapa's Life and his Interpretation of the Great Seal. A Religious Life and Instructional Texts in Historical and Doctrinal Contexts. Hamburg Buddhist Studies 7, series edited by Steffen Döll and Michael Zimmermann. Bochum, Freiburg: project verlag.

Richardson, Hugh Edward. 1959. "Foreword." In Mkhas pahi dgah ston by Dpah-bo-gtsug-lag 'phreng-ba (4 volumes), edited by Lokesh Chandra, vol. 1, ix-xi. Śatapitaka Series no. 9[4]. New Dehli: International Academy of Indian Culture. 
Roerich, George Nicolas, trans./ed. 1988. The Blue Annals. Part I \& II. Delhi: Motilal Banarsidass. [Reprint of Calcutta: Royal Asiatic Society of Bengal, 1949, in two volumes].

Roesler, Ulrike. 2014. "Operas, Novels, and Religious Instructions: Life-stories of Tibetan Buddhist Masters between Genre Classifications." In Narrative Pattern and Genre in Hagiographic Life Writing: Comparative Perspectives from Asia to Europe, edited by Stephan Conermann, and Jim Rheingans, 113-40. Berlin: EB-Verlag.

Schmidt, Dirk. 2015. The Thirty-First Sakya Tridzin, Ngawang Kunga Lodro (access: 15.12.2019).

Seegers, Manfred. 2009. "The Lord of Teachings. Life and works of the Third Karma pa Rang byung rdo rje (1284-1339)”. Master's thesis. University of Kent at Canterbury.

Simmer-Brown, Judith. 2001. Dakini's Warm Breath: The Feminine Principle in Tibetan Buddhism. Boston, London: Shambala Publications.

Stott, David. 1980. "The Historical and Theoretical Background." In The History of the Sixteen Karmapas of Tibet by Karma Thinley, 21-37. Boulder: Prajña Press.

Verhufen, Gregor. 1992. "Die Biographien des achten Karma-pa Mi-bskyod rdo-rje und seines Lehrers Sangs-rgyas mNyan-pa Rin-po-che. Ein Beitrag zur Geschichte der Karma-bKa'-brgyud-pa-Schulrichtung des tibetischen Buddhismus." Master's thesis. University of Bonn.

Vostrikov, Andrew Ivanovich. 1994. Tibetan Historical Literature. Abington, Oxon, UK: Routledge.

Wickham-Smith, Simon. 2012. The Sixth Dalai Lama, Tsangyang Gyatso (access: 15.12.2019). 